\title{
THE FIRST EXPERIENCE OF USING THE BODY INTERACT SIMULATION INTERACTIVE TRAINING PLATFORM AS A PART OF INTERNS' ATTESTATION
}

\author{
М. Ю. Колесник
}

\section{Запорізький державний медичний університет \\ ПЕРШИЙ ДОСВІД ВИКОРИСТАННЯ СИСТЕМИ СИМУЛЯЦИЙНОГО IНТЕРАКТИВНОГО НАВЧАННЯ ВОDY INTЕRАСТ ЯК СКЛАДОВӦ̈ АТЕСТАЦІї ЛIКАРІВ-IНТЕРНIB}

\begin{abstract}
The article presents the first experience of using the Body Interact simulation interactive training system as a stage of interns' attestation. Descriptions and principles of operation with "virtual patient" system are given. The exam procedure with individual workstations installed on laptops is described. The grading criteria and evaluation principles for work with Body Interact system are defined. Examination results of 47 interns in the specialty "Internal Diseases" and "General Practice - Family Medicine" are analyzed according to virtual clinical scenarios "Acute coronary syndrome with ST segment elevation”, "Pulmonary embolism”, "Acute left ventricular insufficiency", "Hypoglycemia” and ”Acute disorders of cerebral circulation”. The main mistakes are identified and systematized on the basis of the analysis of individual step-by-step reports of work results on the simulation training system Body Interact. Steps for optimizing the system and expanding the experience of its usage in order to make the attestation of final courses students are suggested.
\end{abstract}

Key words: simulation-based education; "virtual patient”; attestation; interns.

Анотація. У статті представлено перший досвід використання системи симуляційного інтерактивного навчання Body Interact як етапу атестації лікарів-інтернів. Описано основні принципи роботи із «віртуальним пацієнтом». Викладено методику проведення іспиту з використанням індивідуальних робочих станцій, встановлених на ноутбуках. Визначено критерії та принципи оцінювання роботи на системі симуляційного інтерактивного навчання BodyInteract. Проаналізовано результати іспиту у 47 лікарів-інтернів за фахом «Внутрішні хвороби» та «Загальна практика - сімейна-медицина» за віртуальними клінічними сценаріями «гострий коронарний синдром з елевацією сегмента ST», «тромбоемболія легеневої артерії», «гостра лівошлуночкова недостатність», «гіпоглікемія» та «гостре порушення мозкового кровообігу». Визначено та систематизовано основні помилки лікарів-інтернів на основі аналізу індивідуальних покрокових звітів результатів роботи на системі симуляційного навчання Body Interact. Запропоновано кроки до оптимізації використання системи та розширення досвіду її використання для атестації студентів випускних курсів.

Ключові слова: симуляційне навчання; «віртуальний пацієнт»; атестація; лікарі-інтерни.

Introduction. The implementation of international standardized approaches to the attestation of students and interns in Ukraine requires significant material and organizational efforts. In the context of the unresolved issue of interaction between higher educational and medical institutions, it is especially difficult to conduct practically oriented examinations with the involvement of patients. Every year, for various reasons, patients increasingly refuse to contact with students and interns. Attracting actors to exams in order to simulate the symptoms of various illnesses is unlikely to be the case today, as in Ukraine there are no similar traditions of attestation and their implementation requires considerable time and resources.

Using interactive systems that simulate different standardized clinical situations and offer solutions to evaluate the validity of decisions might be an alternative for solving this issue [3-5]. There are many similar systems in the world practice which can be used both in the educational process and during exams [1].

(C) M. Yu. Kolesnyk 


\section{"PROFESSIONAL AND COMMUNICATION CULTURE OF THE FUTURE DOCTOR: LINGUISTIC, PEDAGOGICAL AND PHILOSOPHICAL ASPECTS”}

At Zaporizhzhia State Medical University the system of simulation interactive training Body Interact Clinical Education is used since 2019. It consists of an interactive panel and licensed workstations with the ability of conducting training or examination session for 50 students or interns at a time. Working with the interactive panel can provide both individual and group problem solution that trains teamwork skills.

In 2019, for the first time in Ukraine, the Body Interact Clinical Education simulation interactive training system was used at Zaporizhzhia State Medical University to conduct the state certification of interns under speciality "Internal Medicine" and "General Practice - Family Medicine”.

The aim - to present first experience and analyze the results of using the Body Interact Clinical Education simulation interactive training system in the format of the final state certification of interns under speciality "Internal Medicine" and "General Practice - Family Medicine".

Methods. The exam was attended by 30 interns of the specialty "Internal Diseases" and 17 interns of the specialty "General Practice - Family Medicine". In advance of exam teachers of the department acquainted the interns with the features of the system Body Interact Clinical Education on the interactive panel. After a teacher's short briefing it was suggested to disassemble one clinical scenario in small group format to acquire skills in order to work with the platform (Fig. 1).

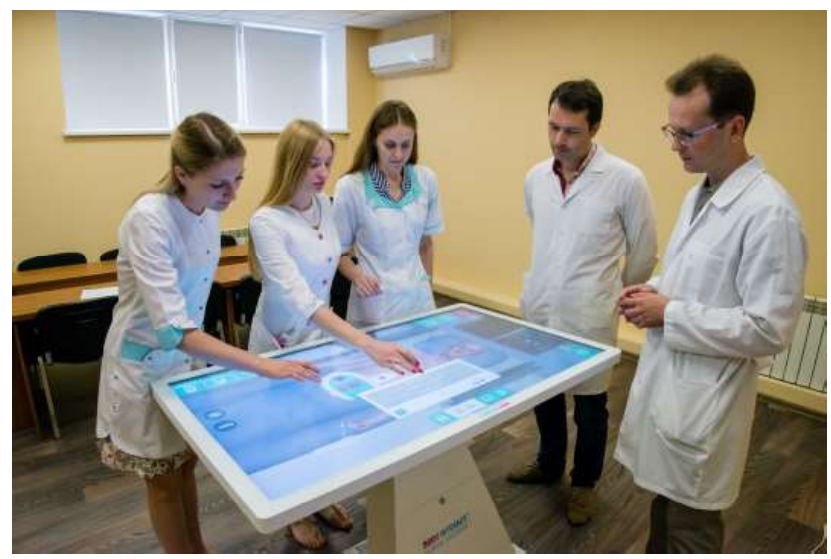

Fig. 1. Group work of interns on the interactive panel Body Interact Clinical Education in a learning format.

The exam took place on workstations installed on laptops, simultaneously for 15 interns. However, the license allows increasing the number of participants to 50 people at one session. As the work involves audio each intern worked in headphones in order not to disturb each other (Fig. 2).

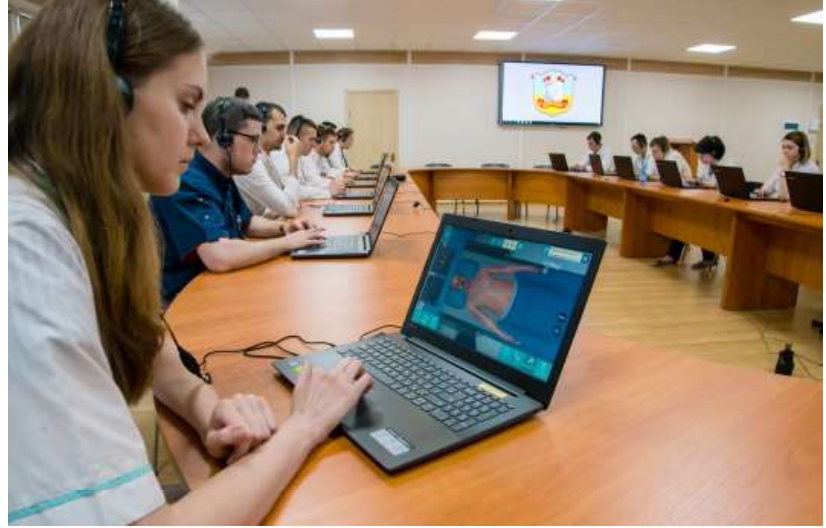

Fig. 2. Individual work of interns on laptops with installed workstations Body Interact.

For each exam session the same scenario was chosen in order to ensure equal conditions. In general, the following scenarios were offered: "Acute coronary syndrome with ST segment elevation complicated by acute left ventricular insufficiency", "Thromboembolia of the pulmonary artery", "Acute left ventricular insufficiency", "Acute disorders of cerebral circulation" and "Severe hypoglycemia". 15 minutes was given in order to complete the task. In case of wrong actions and development of life-threatening condition scenario could be interrupted prematurely. In this case, the result of the exam was assessed as unsatisfactory. In all other cases the results were given as percentages by three categories: "Patient examination", "Diagnostics" and "Treatment". The best result was considered to be the achievement of one hundred percent in all categories. The chronology of assistance and overall result of the case was also additionally analyzed (the patient is cured, death case, the symptoms of patient's disease remain and/or time with the program has finished).

Results. It was noted that the process of acquaintance was rapid enough as the platform Body Interact Clinical Education has sufficiently a user-friendly interface, particularly for modern young people who spend much time with various gadgets.

In general $90 \%$ of interns carried out the task successfully. Maximum result in all three categories of evaluation has been marked in two attestation participants. However the work was completed untimely by $10 \%$ of participants at the workstation because of the failure to provide emergency in life threatening conditions.

Our experience of usage Body Interact Clinical Education has identified the following errors when dealing with "virtual patient":

1. Incorrect diagnosis of the leading syndrome. This is the most serious mistake resulted in faulty algorithm 


\section{Materials of International Scientific and Practical Conference \\ "PROFESSIONAL AND COMMUNICATION CULTURE OF THE FUTURE DOCTOR: LINGUISTIC, PEDAGOGICAL AND PHILOSOPHICAL ASPECTS”}

of the emergency providing, and finally to unsatisfactory result. $10 \%$ of interns had made such mistake and got an overall poor result. Misdiagnosis of pulmonary embolism instead of acute coronary syndrome with ST elevated segment or vice versa were frequently reported.

2. Determination of primary and secondary actions. As the task to be performed is time limited and scenarios usually comprise the development of life threatening conditions therefore the speed of correct decision-making is crucial constituent to meet the challenge of clinical situation successfully.

Example 1. Continuation of history taking disregarding dynamic decrease in oxygen saturation based on pulse oximetry data. This led to late diagnosis of pulmonary edema and poor final result.

Example 2. Administration of unnecessary examination methods in acute coronary syndrome with ST elevated segment. Taking echocardiography and expectation of troponin test results delayed intervention and lowered the overall score.

3. Algorithm of providing the emergency aid in circulatory arrest. This error was ambiguous, as the vast majority of interns stated that they were short of time and were unable to find necessary solutions in the program interface. This cause can't be excluded taking into account that it was really the first operational experience for all interns with this system.

4. Incorrect interpretation of laboratory test results. It should be noted that a number of analyses in the program use measurement units, that are not applied in clinical practice of Ukraine. For example, the glucose concentration is given in $\mathrm{mg} / \mathrm{dL}$ and not in $\mathrm{mmol} / \mathrm{L}$. Some interns regarded the value in other units as severe hyperglycemia, and preferred insulin injection, that led to fatal hypoglycemia.

5. Incorrect choice of therapeutic approach. For example, in acute left ventricular heart failure, intravenous crystalloids were administered instead of inotropic agents. In acute cerebral circulation disorder with impaired swallowing function, peroral administration of drugs was prescribed. The use of great total amount of drugs was also noted, including potential undesirable or contraindicated combinations.

We evaluate the first experience of using Body Interact system as positive and recommend to expand the use of such platforms for both training and certification. In general Body Interact Clinical Education online library comprises hundreds of clinical scenarios (nosological units and syndromes) covering all medical fields in adult and pediatric practice. A variety of life- threatening complications are included in the vast majority of scenarios. The solution of clinical situation involves interactive communication with the "virtual patient" and starts with the history taking.

Some scenarios offer communication with patient's "relatives" if the patient has impairment of consciousness. The history taking in parents is suggested in pediatric scenarios. The system allows to carry out the basic methods of physical examination (palpation, percussion, auscultation) that must be interpreted. The choice of instrumental and laboratory methods of investigation contains a considerable list of advanced diagnostic tests.

Interpretation of the results of additional methods is carried out independently by interns. For example, when choosing ultrasonic examination, echography is suggested, which should identify pathological changes or their absence.

After examination, the therapeutic strategy is chosen and its effectiveness is monitored. Quite often, the scenario is interrupted by the development of a life-threatening condition (ventricular fibrillation, anaphylactic shock) and requires immediate medical treatment. The wrong choice of the latter leads to "death" of the "virtual patient".

It should be noted that all scenarios are based on clinical guidelines of the leading European professional societies and reflect current standards of care. Each scenario contains a list of literary sources that include competent international publications in the last 2-3 years.

A significant advantage of Body Interact Clinical Education is the ability to receive complete chronological answer report of each intern in pdf format. First, it allows you to document the exam process, and second, to analyze introduced errors. Debriefing is performed for each scenario. We offer the right option for solving a clinical problem, dividing all completed steps into primary and secondary.

Conclusions and Prospects for Research. Our experience in using simulation interactive training system Body Interact Clinical Education allows us to confirm the prospects of its use in interns' certification. Its advantages include the possibility of task standardization, time limitation for solving the clinical situation, as well as having criteria for evaluating test results with detailed step-by-step reports.

The pilot experience of applying this system for interns' certification can be expanded and used as the Structured Objective Clinical Examination (OCCI) stage for the sixth-year students [2]. 


\section{Materials of International Scientific and Practical Conference \\ "PROFESSIONAL AND COMMUNICATION CULTURE OF THE FUTURE DOCTOR: LINGUISTIC, PEDAGOGICAL AND PHILOSOPHICAL ASPECTS”}

\section{List of literature}

1. Горшков М. Д. Классификация симуляционного оборудования / М. Д. Горшков, А. В. Федоров // Виртуальные технологии в медицине. - 2012. - № 2 (8). - С. 23-35.

2. Пилипенко М. М. Перший досвід впровадження Британського варіанта екзамену за системою OSCE наприкінці дворічної інтернатури / М. М. Пилипенко, I. Рибінкіна, І. П. Шлапак // Біль, знеболення та інтенсивна терапія. - 2014. - № 3. - С. 5-14.

\section{References}

1. Gorshkov, M.D., \& Fedorov, A.V. (2012). Klassifikatsiya simulyatsionnogo oborudovaniya [Classification of simulation equipment]. Virtualnye tekhnologii v meditsine - Virtual Technologies in Medicine, 2 (8), 23-35 [in Russian].

2. Pylypenko, M.M., Rybinkina, I., \& Shlapak, I.P. (2014). Pershyi dosvid vprovadzennia Brytanskoho variant ekzamenu za systemoiu OSCE naprykintsi dvorichnoi internatury [The first experience of implementing the British OSCE exam at the end of two-year-internship]. Bil, znebolennia ta intensyvna terapiia - Pain, Anesthesia and Intensive Care, 3, 5-14 [in Ukrainian].
3. Філософія симуляційного навчання в медицині / М. М. Корда, А. А. Гудима, А. Г. Шульгай, С. Й. Запорожан // Медична освіта. - 2018. - № 2. - С. 41-46.

4. Abdulmohsen Al-Elq H. Simulation-based medical teaching and learning / H. Al-ElqAbdulmohsen // J. Family Community Med. - 2010. - Vol. 17, No. 1. - P. 35-40.

5. Clinical simulation: importance to the internal medicine educational mission / P. E. Ogden, L. S. Cobbs, M. R. Howell [et al.] // Am. J. Med. - 2007. - Vol. 120 (9). - P. 820-824.

3. Korda, M.M., Hudyma, A.A., Shulhai, A.H., \& Zaporozhan, S.Y. (2018). Filosofiia symuliatsiinoho navchannia $\mathrm{v}$ medytsyni [Philosophy of simulation training in medicine]. Medychna osvita - Medical Education, 2, 41-46 [in Ukrainian].

4. Abdulmohsen, H. Al-Elq (2010). Simulation-based medical teaching and learning. J. Family Community Med., 17 (1), 35-40.

5. Ogden, P.E., Cobbs, L.S., Howell, M.R., Sibbitt, S.J., \& Di-Pette, D.J. (2007). Clinical simulation: importance to the internal medicine educational mission. Am. J. Med., 120 (9), 820-824.
Received 22.04.20

Recommended 24.04.20 